\title{
ATIVISMO JUDICIAL
}

\section{Paulo Junior Trindade dos Santos ${ }^{1}$}

\section{Thelleen Aparecida Balestrin ${ }^{2}$}

Resumo: Investiga-se no estudo a Evolução do Estado de Direito, demonstrando o crescimento tangencial do Poder Judiciário, fortalecido pelos novos modelos Constitucionais, que dão respaldo há uma maior interferência de seus Tribunais. Portanto, o Poder Judiciário passou a "criar direito" por meio de sua atividade, legislando negativamente, pois é este um Poder Político que usa da interpretação jurídica constitucional construtiva, chamada de Ativismo Judicial. Defende-se o Ativismo Judicial Substancialista, que legitima-se pelo Poder Judiciário fortalecido, pelo Poder Constituinte Originário e pelas sociedades democráticas.

Palavras-chave: Estado. Constituição. Jurisdição Constitucional. Ativismo Judicial.

\section{INTRODUÇÃO}

Ao falar em ATIVISMO JUDICIAL, o problema a ser apontado refere-se quanto, à criação de direito por parte de Poder Judiciário, se este realmente é legitimado para esta atividade, que cabe não somente ao Poder Legislativo.

1 Aluno da Associação dos Magistrados do Trabalho da 12 Região (AMATRA12). Bacharel em Direito pela Universidade do Oeste de Santa Catarina (UNOESC). Pesquisador. E-mail:paulojuniortrindadedossantos@hotmail.com

2 Aluna da Escola Superior da Magistratura do Estado de Santa Catarina (ESMESC). Bacharela em Direito pela Universidade do Oeste de Santa Catarina - UNOESC; Aluna da Pós Graduação da Universidade Anhanguera em Direito do Trabalho - pela parceria da LFG. Juíza Leiga, Conciliadora e Mediadora. E-mail: thelleenbalestrin@hotmail.com 
Objetiva-se então, demonstrar que, o Judiciário também encontra-se legitimado para tanto, ocorre assim a Politização do Direito, onde o Judiciário passa a exercer atividade criativa deste, justifica-se na pesquisa no tangente à evolução do Poder Judiciário para com a criação de Direito através de vias hermenêuticas interpretativas constitucionais. Faz-se necessário estabelecer uma ligação entre temas como o Estado, o Direito e a Constituição, sendo estes intrinsicamente interligados, onde deverão ser logo de início abordados, nos quais dividiremos em: O Estado, a Origem e Evolução que surge com a queda da Bastilha e com Tratado de Westfália, assim que houve o declíneo do Estado Monárquico, passoundo a introduzir um novo modelo de Estado criado este pelos ideais iluministas, chamado este de Estado Liberal de Direito . O Estado Social de Direito nasce com as Constituições do México juntamente com a de Weimar, onde neste modelo busca-se o welfare state (Estado de Providência) que fora superado pelo Estado Democrático de Direito em meados do pós-guerras mundial, visando a proteção e efetivação dos Direitos Fundamentais que se encontravam esculpidos nas regras e nos princípios das modernas Constituições. Todos os modelos visavam dar enfoque especial ao Poder Judiciário, desde seu nascimento até a sua contemporaneidade. A Constituição passa a dar amplos poderes ao Poder Judiciário frente ao Estado Democrático de Direito, que é instituído pela Jurisdição Constitucional, através dos Tribunais Constitucionais. Atualmente, denota-se que esta estrutura concretizou-se pelo Neoconstitucionalismo, assegurado por sua carga normativa, em regras e princípios abertos, calcados nos Direitos Fundamentais, conquistados pelas sociedades modernas.

Pela interdisciplinariedade do assunto, perceber-se-à que muitas vezes um tema permeará o outro, tornando assim o trabalho, mais denso, pois os assuntos são similares e não deixam de ter grande relevância. Portanto, resta evidenciar o meio como incide o Judiciário frente a criação do direito, assim sendo, apresentar-se-á, o ATIVISMO JURÍDICO: limites e possibilidades da criação Judicial de Direito, pois este ganha entorno por duas 
correntes, sendo elas: a procedimentalista e a substancialista, e hodiernamente esta última ganha espaço diante das Supremas Cortes, por meio da Hermenêutica e da Interpretação Constitucional, comprometidas com a Supremacia da Constituição emaranhando-se, assim, a Interpretação criadora de direito e a Politização do Direito por meio do Órgão Judicial.

\section{O ESTADO, O DIREITO: TEMAS INBRINCADOS}

Faz-se necessário estabelecer uma ligação entre temas como o Estado, o Direito e a Constituição, sendo estes temas intrinsicamente interligados, pois estes haverão de ser apresentados no primeiro capitulo do trabalho acadêmico, que será dividido em: O Estado: Origem e Evolução; Estado Liberal de Direito; Estado Social de Direito; e Estado Democrático de Direito, pois todos denotam o enfoque ao Poder Judiciário, desde seu nascimento, até a contemporaneidade.

\subsection{O Estado: Origem e evolução}

A origem e evolução do Estado dá-se pela necessidade de se sair do Estado Absolutista, para um estado racional, doutrina que fora estabelecida pelos iluministas, chamando o novo Estado de "Governo das Leis", que visavam limitar o poder do Estado através da lei, servindo esta de antídoto natural do poder monocrático, passando o Estado a ser regulado por essa Carta de Direitos Políticos, para que o poder não voltasse a ser irracional, onde há de se mencionar, que no antigo modelo de Estado tolhido pela irracionalidade.

Importante destacar, que o poder passou a incidir-se pela lei, "[...] sinalizando a emancipação Política e Civil das classes sociais, fazendo nascer o poder do Povo e da nação sua legitimidade incontestável." 3

3 MULLER, Célia. Os direitos fundamentais do consumidor no Estado Democrático de Direito. In: BAEZ, Narciso Leandro Xavier; BARRETO, Vicente (Orgs.) Direitos Humanos em evolução. $1^{a}$ ed. Joaçaba: Ed. UNOESC, 2007. P. 267. 
Deve-se lembrar que a criação e aplicação da lei era somente ao soberano, pois, para superar este Estado de Medievo, criarse-ia um pacto social entre os cidadãos e o Estado, onde os primeiros abririam mão de sua liberdade em prol da proteção do segundo, formalizando o então denominado Estado Natural, que por vias do contrato social, criou-se o Estado Civil.

Suscintamente, o contrato servia como instrumento de passagem do momento negativo de natureza para um estágio político social, corporificando-se desta forma a dar racionalidade diante do Estado e da sociedade. A passagem para o Estado Moderno deu-se por alguns fatores históricos de grande relevância, sendo eles, a queda da Bastilha e o Tratado de Westfália, pois fora, neste momento que se materializou o governo das leis, com a Constituição Escrita.

\subsection{O Estado Liberal de Direito}

Assim nasce o Estado de Direito Liberal, também podendo ser chamado de Clássico, que nasceu a partir da metade do século XIX; institucionalizando-se na Alemanha e na França com o surgimento da Revolução Francesa de 1789, constituindo assim o primeiro regime jurídico-político, haja vista, que em momento próximo eclode também na Inglaterra e logo após nos Estados Unidos da América, a partir de então várias outras nações declararam sua independência criando este novo modelo de Estado. Alguns doutrinadores salientam que foi na Inglaterra, juntamente com a criação do Estado, que nasceu a Constituição, que esta vinha a assegurar as liberdades negativas dos cidadãos, com o mínimo de intervenção, ou seja, o direito público passa a intervir muito menos diante do privado, fundando-se assim, a administração do Estado avençada no princípio da pura legalidade. Desta forma, o direito reduz-se a lei, considerada esta como a única fonte de Direito, tendo como responsável pela sua produção o Poder Legiferante. Nesse diapasão explicita Bobbio: 
[...] continua e progressiva erosão do poder absoluto do rei, em períodos históricos de crise mais aguda, de uma ruptura revolucionária (exemplares os casos da Inglaterra do século XVII e da França do fim do Século XVII); racionalmente, o Estado Liberal é justificado como resultado de um acordo entre indivíduos inicialmente livres que convencionaram estabelecer os vínculos estritamente necessários a uma convivência pacífica e duradoura. ${ }^{4}$

Fator de crucial importância a se apresentar, é de que o poder político transfere-se da pessoa do governante, para uma entidade abstrata: o Estado. Analisar-se-á proficuamente a divisão em que se faz o Estado de Direito, entre sua materialidade e formalidade, onde a primeira se vale ao conteúdo a que se refere a ação estatal e a relação entre Estado e Cidadão (a divisão dos poderes, o princípio da legalidade, a vinculação do juiz a lei, a garantia de proteção jurídica e de abertura da via judicial para com os cidadãos), e a segunda refere-se a atuação estatal restrita a legalidade que passa a servir de freio as autoridades.

O povo passa a ser o soberano do Estado, onde será representado pelos parlamentos, ou seja, pelo Poder Legislativo, devendo estes obedecer a "vontade do povo". Neste diapasão, Santiago Mir Puig, aponta que o Estado Liberal, e o "[...] Estado governado pelo Direito emanado da vontade geral, expressada pelos representantes do povo, na qual radica a soberania nacional, em contraposição ao Estado absoluto, no qual o Direito se encontra em mãos de um ou vários homens. ${ }^{5}$

Neste tópico, juntar-se-á, o passado com o presente, quanto ao que tange ao Poder Judiciário, que neste modelo era considerado a mera "boca da lei". Na atualidade, este passa

4 BOBBIO, Norberto. Liberdade e Democracia. 4o. ed. São Paulo: Editora Brasiliense, 2000. P.14.

5 [...] de Estado gobernado por el Derecho emanado de la voluntad general, expresada por los representantes del pueblo, en el cual radica la soberanía nacional, en contraposición al Estado absoluto, en el que el Derecho se halla en manos de uno o varios hombres. (PUIG, Santiago Mir. EI Derecho Penal en EI Estado Social y Democrático de derecho. $1^{\text {a }}$ ed. Barcelona: Editora Ariel, 1994. P. 32.). 
por uma expansão no que se refere ao seu papel político, ocorrendo assim o chamado Ativismo Judicial ${ }^{6}$. Portanto, durante a explanação do trabalho em alguns momentos falar-se-á na crise legalista e na crise do positivismo jurídico.

\subsection{O Estado Social de Direito}

Já o Estado de Direito Social, supera o modelo anterior analisado, pois como se verá, esse modelo visa o clamor social que os cidadãos vinham a procurar, desta feita, buscou-se proficuamente pelas garantias individuais dos cidadãos e pelo cumprimento dos direitos sociais reconhecidos até então.

Além disso, o Estado social é a "[...] troca, supõe a intenção de derrubar as barreiras que no Estado liberal separam o Estado e a sociedade." 7

A estrutura jurídica e política frente a uma organização social e popular, faz surgir assim, os direitos sociais e trabalhistas, que passarão a ser institucionalizados Constitucionalmente, onde passam a serem esses tratados como Direitos Fundamentais de Segunda Geração. Como nascedouro histórico, a Constituição de Weimar na Alemanha, e a Constituição do México e por fim a Revolução Russa Social dos Trabalhadores. Muller expõe:

O Estado Social representou a superação ideológica do antigo liberalismo. Esse entrou em crise por não resolver o problema essência da ordem econômica, das camadas proletárias da sociedade, que se achavam à margem da vida e não equacionando, via de consequência, as contradições sociais. ${ }^{8}$

6 AGUIAR, Thais Florencio de. A judicialização da política ou o rearranjo da democracia liberal. Ponto-e-Vírgula, 2: 142-159, 2007. P. 150. Disponível em: <http:// www.pucsp.br/ponto-e-virgula/n2/pdf/11-thais.pdf>. Acessado em: 29, de janeiro de 2008.

7 [...]cambio, supone el intento de derrumbar las barreras que en el Estado liberal separaban a Estado y sociedad. (PUIG, Santiago Mir. EI Derecho Penal en EI Estado Social y Democrático de derecho. $1^{\text {a }}$ ed. Barcelona: Editora Ariel, 1994. P. 32.).

8 MULLER, Célia. Os direitos fundamentais do consumidor no Estado Democrático de Direito. In: BAEZ, Narcizo Leandro Xavier; BARRETO, Vicente (Orgs.). Direitos Humanos em evolução. 1a. ed. Joaçaba: Ed. UNOESC, 2007. P. 02, 100. 
Os juízes como também ver-se-á, ganham novas funções, sendo de salutar importância apontar a criação da Justiça Constitucional elaborada por Kelsen e o caso paradigmático NorteAmericado de Marbury vs. Madson, nestes dois momentos, verse-á que as atribuições dos Juízes se tornaram mais amplas, por meio dos fatores históricos acima apontados.

Ver-se-á, que o modelo de Estado de Direito Social Americano, e chamado de Welfare State (Estado de Providência), que se pautará pelo bem estar coletivo, buscando, sempre a concretização e a realização dos programas sociais. A lei neste modelo de Estado tem novas finalidades como se verá.

\subsection{O Estado Democrático de Direito}

O Estado Democrático de Direito representa o advento estabelecido pela modernidade, lapidando-se nas Constituições Modernas, e este se normatizou por via de regras e princípios, trazendo assim grande carga axiológica e principiológica a esta, valorando assim por meio dos Direitos Fundamentais, a realização e efetivação da proteção direitos individuais, difusos e coletivos, visando a proteção das minorias frente às maiorias.

Por ter uma Constituição de perfil mutante, seus conteúdos não ficam mais congelados ou rígidos, agregando-se assim os princípios democráticos, momento este em que a democracia passa a se vincular inteiramente ao Estado de Direito.

Assim, neste modelo de Estado, que demonstrar-se-á que é altamente avançado, vige o Princípio da Supremacia Constitucional, que visa amplamente as garantias e liberdades de direitos individuais e sociais, visando sempre o bem-comum, por meio de preceitos de justiça social e substancial, e sempre com a consonância dos Direitos Fundamentais.

Os princípios deste modelo de Estado serão apresentados para que se perceba que, surgem para que se superem as desigualdades sociais, e que se instaure um regime democrático que venha a realizar a justiça social. No que tange a lei, ver-se-á, a 
exigência da escolha dos representantes legislativos, pelo povo, para que estes venham a representá-los, haja vista, que estes não o fazem, pensando na proteção das minorias e sim no das maiorias.

Neste mesmo sentido aponta Ruy Samuel Espíndola, que:

O Estado Democrático de Direito pressupões uma série de tarefas políticas, sociais, econômicas, culturais, traduzidas por normas tarefas e normas fins, por missões constitucionais plasmadas no texto fundamental, que se expressam através do que tradicionalmente chamamos de normas programáticas; também o amplo leque de direitos fundamentais individuais, econômicos, políticos e culturais que encontramos no sistema de direitos e garantias fundamentais, expressam os principais valores a serem perseguidos e realizados em um Estado Democrático de Direito. ${ }^{9}$

Como se analisar-se-à o modelo de Estado Democrático de Direito, este divide-se em: substancialista, ${ }^{10}$ que trata este da realização e efetivação dos Direitos Fundamentais, e da própria democracia em si, já no que se falará em procedimentalista ${ }^{11}$ este passa a incidir em tarefas políticas de legislação, que este será reputado ao longo do trabalho, pois se aceita por lógica a teoria da substancialidade que vem a ser aplicada esta pelo Judiciário.

Contudo isso, alarga-se a democracia, questão concernente ao papel do Poder Judiciário, "[...] e em particular da jurisdição constitucional nos ordenamentos em que estão em vigor, formas do judicial review of legislation." 12

Logo após o momento de criação das Constituições Dirigentes, veio a ocasionar uma grande tensão de poderes entre

9 ESPINDOLA, Ruy Samuel. Jurisdição Constitucional Estadual. Revista Direito Público. Pág. 383 - 384. Disponível em :<hattp://201.38.128.50/ojs/index.php/direitopublico/article/view/86>. Acessado em: 13 de mao de 2008.

10 STRECK, Lênio Luiz; MORAIS, José Bolzan de. Ciência Política \& Teoria do Estado. $5^{\text {a }}$ ed. Porto Alegre: Editora Livraria do Advogado, 2006. P. 104.

11 STRECK, Lênio Luiz; MORAIS, José Bolzan de. Ciência Política \& Teoria do Estado. $5^{\mathrm{a}}$ ed. Porto Alegre: Editora Livraria do Advogado, 2006. P. 155.

12 LAQUIĖZE, Alain. État de droit e soberania nacional na França. In COSTA, Pietro; ZOLO, Danilo (Orgs.).O Estado de Direito. História, teoria, crítica. $1^{\mathrm{a}}$ ed. São Paulo: Martins Fontes. São Paulo 2006. P. 544. 
as suas três Esferas Políticas, criando-se assim, um check and balances, onde a Corte Constitucional por via da Jurisdição Constitucional, pode este regular os demais poderes, através de um controle de constitucionalidade, e dos atos administrativos (difuso, concentrado e misto), chamada esta pelos americanos como review of legislation, que assim, juntamente com a Democracia Substantiva, nasce o aclamado Ativismo Judicial, passando, assim o Poder Judiciário exercer grande atividade de regulação diante dos demais Poderes.

\section{A CONSTITUIÇÃO E O PODER JUDICIARIO FRENTE AO ESTADO DEMOCRÁTICO DE DIREITO}

A Constituição e o Poder Judiciário frente ao Estado Democrático de Direito apresentar-se-á, dando alguns enfoques: primeiramente, A Constituição e o seu sentido frente ao Estado democrático de Direito; Movimentos Constitucionalistas; O Poder Judiciário e o Estado Democrático de Direito; Jurisdição Constitucional e Tribunal Constitucional. Assim, por muitas vezes um tópico adentrará ao assunto do outro, tornando assim o trabalho, mais denso, pois os assuntos apresentam alto grau de similitude e não deixam de ter grande relevância.

\subsection{A Constituição e Seu Sentido no Estado Democrático de Direito}

O sentido de Constituição frente ao Estado Democrático de Direito, que visa estampar os Direitos Fundamentais, devendo assegurá-los, para que se evite o abuso de poder por parte dos Governantes do Estado, ainda vê-se a incidência de uma vultosa valorização do jurídico-político.

Destarte, as Constituições democráticas lançam-se no terreno argumentativo, buscando a efetivação de suas normas invocando, "[...] direitos qualificados e fundamentais, os quais são positivados nos textos das Constituições, por meio de regras 
e princípios que se apresentam como espécie do gênero normas jurídicas." 13

Aponta Kelsen, ensinando que a Constituição encontra-se no ápice da pirâmide normativa, onde as suas normas dividemse em regras e princípios, por meio do qual a Constituição ganha ampla abertura axiológica, justamente no que se tange o campo interpretativo e hermenêutico constitucional, tornando estes elementos que se justificam como criadores e efetivadores de direito, passando assim a tutelar os direitos subjetivos, por via da democracia constitucional.

Considera-se que no Estado Democrático de Direito, através de sua Constituição, passa a dispor de mecanismos operacionais na implementação de medidas para com a realização de direitos e garantias fundamentais, mas estes acabam não sendo eficazes, pois os órgãos Executivo e Legislativo, não conseguem realizá-los. Desta forma, recai assim, sobre o Judiciário o controle estatal para que venha a garantir e realizar de forma eficaz desses direitos, onde é salutar apresentar a idéia de Bolzan, citado por Streck, que:

Estamos, assim, em face de um sério problema: de um lado temos uma sociedade carente de realização de direitos e, de outro, uma Constituiçao Federal que garante estes direitos da forma mais ampla possível. Este é o contraponto. Daí a necessária indagação: qua é o papel do Direito e da dogmática jurídica neste contexto? Segundo Morais, o Estado Democratico de Direito, teria (tem?) a característia de ultrapassar não só a formulaçao do Estado Liberal de Direito, como também a do Estado Social de Direito - vinculado ao Welfare State neocaptalista - impondo à ordem jurídica e à realidade. O Estado Democratico de Direito, ao lado do núcleo liberal agregado à questão da igualdade como um conteúdo próprio a ser buscado garantir através do asseguramento mínimo de condições

13 GOMES, Sergio Alves. Hermenêutica Jurídica e Constituição no Estado de Direito Democrático. Rio de Janeiro: Forense, 2001. P. 01. 
mínimas de vida ao cidadão e à comunidade. Ou seja, no Estado Democrátio de Direito a lei passa a ser, privilegiadamente, um instrumento de açao concreta do Estado, tendo como métoo assecuratório de uma efetividade a promoção de determinadas ações pretendidas pela ordem jurídica. ${ }^{14}$

Resumindo este emaranhado de informações e trazendo a lume o pacto constituinte, que por este devem ser inseridos na Constituição frente ao Estado Democrático de Direito, este vem reconstruir e dar possibilidades para um amplo acesso a jurisdição constitucional, buscando a efetivação, nesta Constituição, de regras e princípios abertos, que visem resguardar os Direitos Fundamentais, até o momento conquistados, também superando os antigos modelos de Estado de Direito.

A Jurisdição Constitucional incide por meio do controle de constitucionalidade, por via concentrada e difusa, os meios operacionais para que se garanta a realização deste modelo de Estado, que pelo judiciário este controle visa garantir e realizar de forma mais contumaz os direitos expresso nestas Cartas Magnas. Ultima-se que cabe ao Poder Judiciário, a efetivação da Constituição por via de seus princípios e regras, por meio de suas decisões. Haja vista, neste modelo de Estado o juiz não mais pode ser considerado a mera boca da lei, passando a ser um efetivador das promessas, pela via Constitucional, que assim chegar-se-á a um Ativismo Judicial Substancialista.

\subsection{Movimentos Constitucionais}

Os Movimentos Constitucionais passaram a evoluir juntamente com o Estado juntamente com a Evolução dos Direitos Fundamentais, tendo uma simbiose, que se percebe desde seu nascimento até o Neoconstitucionalismo.

14 MORAES, José Luiz Bolzan. Do Direito Social aos Interesses Transindividuais. Porto Alegre, Livraria do Advogado, 1996. PP. 67 e segs. apud STRECK. Lênio Luiz. Hermenêutica e(m) crise. Porto Alegre: Livraria do Advogado, 1999. P. 36 - 37. 
Salutar que se mencione que as Constituições devem ser submetidas aos seus sentidos formais e substanciais, passando a ganhar alto grau de substancialidade, pois assim a Constituição se torna produto de maior significado interpretativo/hermenêutico, momento em que realmente ganha esta substancialidade sendo dados histórico e paradigmático na decisão de Madson e com a Criação da Jurisdição Constitucional formulada por Kelsen. Vale lembrar, que cada um desses modelos nasce de sistemas jurídicos opostos (civil law e common law).

Quanto a esse Movimento Constitucional, há de se falar que houve uma, "[...] implementação e difusão de Tribunais Constitucionais por todos os continentes é decorrência inevitável do desfecho histórico do constitucionalismo." 15

Não é suficiente, desse modo, explicitação baseada na tese de que a Europa optou por Tribunais ad hoc em face de não existir, no modelo romano-germânico, a figura do stare decisis, optou a conceder efeito erga omnes às decisões. É razoável sustentar, destarte, que a razão a exclusão do juiz ordinário do controle de constitucionalidade baseia-se muito mais me motivações de ordem pública, que deita raízes na Revolução Francesa, em especial na discussão acerca da noção de soberania popular. [...] É que, na Europa, a opção que se colocava não era entre a criação de um Tribunal Constitucional e a adoção de um controle difuso à americana. A instituição de um sistema de fiscalização concentrado visou antes a afastar os magistrados europeus do controle da constitucionalidade. ${ }^{16}$

Por tudo isso, ver-se-á que os Tribunais passarão a tomar decisões incisivas de carga principiológica, diante de quadros políticos importantes a que venham tratar de Direitos Fundamentais, protegidos estes sobre a égide da Constituição.

15 JAYME, Fernando Gonzaga. Tribunal Constitucional: exigência democrática. Belo Horizonte: Editora Del Rey, 1999. P. 25.

16 MEDEIROS. P. 42.; apud STRECK, Lênio Luiz. Jurisdição Constitucional e Hermenêutica - Uma nova crítica do direito. Porto Alegre: Livraria do Advogado, 2002. P. 305-307. 
Demonstra-se também a transformação que é trazida pelo desapego quanto ao dogmatismo e ao formalismo jurídico em busca de um judiciário democrático, através de Tribunais Constitucionais, devendo estes acharem uma solução por via interpretativa construtiva com os elementos dados pela atual Hermenêutica Constitucional.

Conclui-se que os Movimentos Constitucionais, fazem com que se torne crescente o viés de abertura interpretativa/ criadora da Lei Fundamental, podendo o juiz, decidir por meio de suas regras e princípios calcados na efetivação e realização dos Direitos Fundamentais, através da Jurisdição Constitucional, que serve de check and balances.

\subsection{O Poder Judiciário e o Estado Democrático de Direito}

O Poder Judiciário em sua contemporaneidade tem como aliado o Estado Democrático de Direito, pois elevam à efetivar, os direitos fundamentais, e os princípios esculpidos nas Modernas Cartas Políticas, legitimando-se por esses argumentos, onde também deve-se mencionar, que alguns outros fatores contribuíram para esta influência do ora poder, sendo que, os países democráticos acabaram de criarem Tribunais Constitucionais, devido à sociedade democrática é muito dinâmica, perante ao legislativo e executivo.

Vê-se que o Poder Judiciário frente ao Estado Democrático de Direito tem como escopo fundamental, buscar a efetivação dos Direitos Fundamentais e dos Princípios Constitucionais esculpidos nas Constituições, sendo que, a sua expansão dar-se-á por via das sociedades democráticas contemporâneas, surgindo no pós-guerra o fortalecimento da Jurisdição Constitucional, onde passa a ter um novo rearranjo, onde o Poder Judiciário assume a "hegemonia no arranjo político-institucional"17.

17 LIEBERMAN, J. K.. The Litigious Society, Nova lorque, Basic Books, 1981, p. 186.: apud GARAPON, Antoine. O juiz e a democracia. O guardiao das promessas. Tradução: Maria Luiza de Carvalho. $2^{\mathrm{a}}$ ed. Rio de Janeiro: Revan, 2001. P. 26. 
Pelo exposto, o Poder Judiciário passa a realizar políticas públicas, se tornando um meio mais acessível e adequado para que se efetive e realize-se a Lei Fundamental, passando assim a ter legitimidade do interprete criador do Direito, por meio do que se arrolou acima, e ainda ganha vida por meio do Poder Constituinte Originário; com o dever de operar por força de suas decisões políticas.

Portanto, salienta-se que uma elevada aceleração e expansão judicial, que passa a explodir, diante dos anseios da sociedade democráticas contemporâneas, pela abertura do seu acesso à todos, conforme estabelecido nas Constituições. Haja vista, que "[...] não nos tornamos mais litigantes porque as barreiras processuais caíram. A explosão do número de processos não é um fenômeno jurídico, mas social. Ele se origina da depressão social que se expressa e se reforça pela expansão do direito"."18

Fator histórico importante para que viesse a ocorrer o fortalecimento Judicial e o caso de Marbory, onde este poder passou a ter diante de suas decisões alto grau de substancialidade, introduzindo assim o judicial of legislation.

Chega-se a conclusão do ensinamento aludido, que o Estado Democrático de Direito, encontra acolhimento existencial, dentro de um corpo hermenêutico estrutural que passa a dar condições de agir legitimamente, cabendo ao Poder Judiciário fazer com que se opere a Justiça Constitucional, agasalhando os fundamentos deste modelo de Estado de Direito, fazendo-se cumprir as políticas publicas não realizadas pelos demais poderes estatais.

No que se refere à suas decisões, estas passam a ser fonte do direito ganhando vida e viabilidade por intermédio de suas interpretações construtivo-criativas.

\subsection{Jurisdição Constitucional}

A Jurisdição Constitucional ganha força através da separação/tripartição dos poderes, que pelo ente chamado de

18 CAPPELLETTI, Mauro. Juízes Legisladores? Tradução: Carlos Alberto Álvaro de Oliveira. Porto Alegre: Fabris, 1993. P. 55. 
Tribunal Constitucional (Poder Judiciário), tem como sua fórmula a busca pelo equilíbrio entre os demais poderes. Novamente Cappelletti, passa a contribuir que:

[...] estão se movimentando nesta direção, partindo do sistema de rígida separação para o sistema de controles recíprocos. Sistema, este ultimo, no qual o "crescimento" do poder judiciário é obviamente o ingrediente necessário do equilíbrio dos poderes. Podem ser vistos exatamente a essa luz o nascimento e crescente importância adquirida pelos tribunais administrativos e constitucionais na Europa (e não apenas na Europa). ${ }^{19}$

Quebrando o paradigma dos antigos modelos de Estado de Direito, a Jurisdição Constitucional, ganhou enorme espaço, nas Constituições Democráticas, dando-lhes, ar de contemporaneidade, fazendo com que se crie através deste um poder de efetivação, realização, concretização e de cumprimento das Cartas Magnas modernas.

Passando o Poder Judiciário a fazer parte da arena política, servindo assim de elemento essencial para o Estado de Direito Democrático, que passou a ser consubstanciado pelas Constituições Modernas, este é dotado de normas constitucionais de eficácia.

\subsection{Tribunal Constitucional}

Há de se destacar, que os Tribunais Constitucionais, servidos de Jurisdição Constitucional, estão encarregados pela defesa, realização e efetivação das Constituições, através da interpretação e aplicação de normas constitucionais, calcandose, pela:

[...] manutenção da unidade política, ao julgar os conflitos de competência entre as diversas esperas políticas estatais, promovendo a defesa da Constituição. Na apreciação das tarefas da Jurisdição

19 Idem. P. 32. 
constitucional destaca a tutela dos direitos fundamentais como atributo de sua essencialidade. ${ }^{20}$

Amealhando, os conceitos vistos acima, a cerca dos Tribunais Constitucionais, este tem como atividade "[...] a conservação da Constituição, é, justamente, também essa garantia, elemento essencial de sua tarefa." ${ }^{21}$

Os Tribunais Constitucionais tem como finalidade controlar os Parlamentos, passando a ser o Guardião das Promessas como assim diz Garapon, ou seja, é o guardião da Lei Fundamental, onde passa a ter grande influencia social, efetivando-se por sua interpretação/criação, tomando assim decisões com força política, para que assim, se mantenha a unicidade Constitucional.

Por fim, vale destacar que a este órgão cabe tomar estas decisões, que por fim demonstram grande força política, pois resolvem em última instância, problemas constitucionais de especial sensibilidade política, mas também porque tem influência determinante junto dos outros tribunais a exercer um papel condicionante do comportamento dos órgãos de direção política. $^{22}$

\section{O ATIVISNO JUDICIAL}

No terceiro capítulo, busca-se demonstrar o meio como incide o Judiciário frente à criação do direito, assim sendo, apresentar-se-á o Ativismo Jurídico, dividindo-se o estudo em $\mathrm{O}$ Ativismo Judicial: conceitos e fundamentos. Após apresentarse-á seus dois eixos, o Procedimentalista e o Substancialista, demonstrando-se também a importância da Hermenêutica e da Interpretação Constitucional, e para dar fechamento a esse

20 HESSE, Konrad. Elementos de Direito Constitucional da República Federal da Alemanha. Tradução (da $20^{a}$ Edição alemã) Luís Afonso Heck. Porto Alegre: Fabris, 1998. P. 423

21 CANOTILHO, José Joaquim Gomes. Direito Constitucional - e teoria da constituição. $6^{a}$ ed. Coimbra: Almedina, 1993. P. $283-284$.

22 GARAPON, Antoine. 0 juiz e a democracia. O guardiao das promessas. Tradução: Maria Luiza de Carvalho. $2^{a}$ ed. Rio de Janeiro: Revan, 2001. P.39 
emaranhado de elemento apresentar-se-á, a Interpretação criadora de direito, e a Politização do Direito pela via Judicial.

\subsection{O Ativismo Judicial: Conceitos e Fundamentos}

Ativismo Judicial apresenta-se como uma teoria nascida juntamente com o Estado Democrático de Direito e os Tribunais Constitucionais, onde o Poder Judiciário por meio de suas decisões passa a criar direito, tornando-se um poder de grande aceitabilidade social, sendo que foi legitimado pelo Poder Constituinte Originário, e deteve a bênção de se tornar o Guardião das Constituições, onde não passa a ser tratado como mera boca da lei. Por isso as suas decisões têm cunho com alta carga política, que afetam por vezes políticas públicas ou também as esferas públicas.

Portanto, a invasão do Tribunal/Juiz se efetiva diante da soberania popular, calcada na democracia, por meio do viés estabelecido pelo Estado Democrático de Direito se reveste pelas Constituições modernas, passando a ter grande popularidade, sendo vistos como os heróis da modernidade, ler-se-ia ainda como, os Guardiões dos Direitos Fundamentais e do Princípio da Dignidade humana, apresentando assim, uma nova forma de conceber a democracia:

A irrupção do ativismo jurídico só poderá ser compreendida se relacionada a um movimento profundo, do qual ele é apenas uma das manifestações. Não se trata de uma transferência de soberania para o juiz, mas sobretudo uma transformação da democracia. A grande popularidade dos juizes está diretamente ligada ao fato de que foram confrontados com uma nova expectativa política, da qual se sagraram como heróis, e que encarnaram uma nova maneira de conceber a democracia. ${ }^{23}$

Saliente-se que o juiz não é mais considerado a "mera boca da lei", na atualidade por intermédio da Constituição faz com

23 DWORKIN, Ronald. O Império do Direito. $1^{\text {a }}$ ed. São Paulo: Martins Fontes, 1999. P. 09-15 
que se efetivem os direitos, através de suas decisões, incidindo estas por vezes como sendo decisões de cunho político.

Por todo o exposto, na atualidade o Juiz/Tribunal deve interpretar construtivamente/criativamente com a aplicação de suas decisões. Fator de salutar importância a demonstrar-se foi à brutal expansão do Direito Legislativo, assim passa o Judiciário a ganhar papel de destaque frente à realidade social em que se vive.

Apontam alguns autores que o mero ato de aplicar o direito torna a criá-lo automaticamente, por meio da interpretação e da Hermenêutica Constitucional adequada. Desta forma, o Ativismo Judicial é um forte poder nas mãos dos juízes que inquestionavelmente "[...] "criam novo direito" toda vez que decidem um caso importante. Anunciam uma regra, um princípio, uma ressalva a uma disposição [...] o Direito é a nossa instituição social mais estruturada e reveladora." 24

A atividade do Judiciário se concretiza por meio da Jurisdição Constitucional, que lhes dá o poder no que se fala em controle de constitucionalidade. Também neste, buscou-se distinguir a Lei do Direito, pois estes não são a mesma coisa, como confundiam no Estado Liberal de Direito, sendo que o atual modelo de Estado busca separar os conceitos.

$\mathrm{O}$ ativismo se apresenta diante de dois eixos doutrinários, sendo um procedimentalista e outro substancialista.

\subsubsection{O Ativismo Judicial Procedimentalista}

No que tange ativismo judicial procedimentalista, este defende a invasão do direito no campo político, pois este só vem a gerar problemas, sendo assim, estabelece-se o direito dos preceitos de justiça, liberdade e igualdade.

Quanto à ponderação, no sentido de que o direito passa a invadir o campo político, através de preceitos de igualdade,

24 STRECK, Lênio Luiz. Jurisdição Constitucional e Hermenêutica - Uma nova crítica do direito. Porto Alegre: Livraria do Advogado, 2002. P. 158 
liberdade e justiça, porquanto a relação política e de direito, há de se ressaltar, conforme o exarado por Lênio Streck, que:

Por último, altera-se a relação entre política e o Direito. Uma vez que o Direito já não está subordinado à política como se dela fosse instrumento, senão é a política que se converte em instrumento de atuação do Direito, subordinada aos vínculos e a ela impostos pelos princípios constitucionais: vínculos negativo, como os gerados pelos direito às liberdades que não pode ser violado; vínculos positivos, como os gerados pelos direitos sociais, que devem ser satisfeitos. ${ }^{25}$

Conquanto, o Direito não se serve apenas do campo político, pois mais claro fica, que a política se transforma em instrumento de atuação do Direito, fica então subordinada a este, formando assim, uma sociedade de parceiros do Direito, livres e iguais.

Somente o Direito produzido/criado pelo Poder Legislativo e legítimo, se passado este por um processo político, segue os fundamentos de um Estado Liberal e de Direito racionalizador. Assim os Tribunais devem se restringir pela presença do Direito, onde sendo assim a justiça no que fala a esta doutrina só se realiza segundo razões de "Direito e da Lei".

O processo democrático para o eixo em comento desempenha a ação de planejamento do Estado, perante a vontade dos cidadãos, dotados estes de soberania popular. Já quanto ao processo político quando atingir o democrático vem ferir a corrente procedimentalista.

O Poder Político deve ter como obrigação que a sua autoridade normativa venha a se fundir no Direito, aonde vem a se desenvolver por um código jurídico institucionalizado.

Nesta teoria o Poder Judiciário é visto como mero fiscalizador da lei, voltando-se ao Estado Clássico de Direito, fundado

25 KELSEN, Hans. Teoria Geral do Direito e do Estado. $3^{a}$ ed. São Paulo: Martins Fontes, 2000. P. 216 
em um "governo das leis", onde nenhum dos poderes pode intervir diante da esfera do outro.

Este modelo também busca o retorno do rigorismo ao princípio da legalidade, onde somente compete-lhes ao Poder Legislativo a criação de direito, apontando suas teoristas, que este vem a representar de forma mais adequada às sociedades democráticas.

Neste eixo o juiz deve ser extremamente racional, voltando a ser somente o aplicador das leis, fazendo com que este poder silencie-se diante de atrocidades acometidas pelos demais poderes estatais.

A jurisprudência criada evidentemente pelo Poder Judiciário é considerada agressiva, pois guarda em si cunho de abstração, onde o intérprete constitucional deve lançar mão de argumentos políticos.

\subsubsection{O Ativismo Judicial Substâncialista}

Já o segundo eixo, ou seja, o Substancialista adota que o Poder Judiciário por meio de suas decisões possa criar direito, ou seja, usando-se de uma interpretação construtiva (Dworkin), havendo assim de se analisar que tanto o processo legislativo, quanto ao judiciário detém natureza substancial, onde ambos são legitimados para com a atividade construtivo-criadora de direito, onde a criação de direito por parte do judiciário nasce de suas decisões.

A função criadora do Direito dá-se por intermédio do Poder Judiciário, revelada por meio da decisão, que tem caráter precedente, diante do direito de família anglo-saxônica. Lê-se Jurisprudencial, para o direito da família romanístico, pois diante destes dois sistemas de direito, incidem as decisões como sendo, normas, que vem a calhar sobre os casos concretos, Kelsen explica, que esta:

A função criadora de Direito dos Tribunais é especificamente manifestada quando a decisão judicial tem o caráter de um precedente, ou seja, quando 
a decisão judicial cria uma norma geral. Onde os tribunais estão autorizados não apenas em aplicar Direito substantivo preexistente nas suas decisões, mas também a criar Direito novo para casos concretos, existe uma compreensível tendência de se dar a essas decisões judiciais o caráter de precedentes. Dentro de tal sistema jurídico, os tribunais são órgãos legislativos exatamente no mesmo sentido em que o órgão é chamado legislativo no sentido mais restrito e comum do termo. ${ }^{26}$

Conclui Kelsen, que esse "[...] tipo de criação de Direito deve ser claramente distinguido da criação de normas gerais através da prática permanente dos tribunais [...]" ${ }_{27}$, que o Direito passa a dar efetiva tutela jurisdicional substantiva, por meio de princípios.

Os juízes no substancialismo, guardiões dos textos constitucionais, dividem em normas e princípios, que são plasmados e abertos, onde esse texto nasce da evolução dos Direitos Fundamentais, onde os guardiões devem buscar a realização e efetivação destes.

Portanto, o Ativismo Judicial Substancalista admite a invasão da política no direito, contrariamente a que afirma os Procedimentalistas. Sendo assim, os Juízes devem aplicar a Constituição de forma dinâmica, por meios de argumentos políticos, tratados estes como questões de princípios de moral e de política. Ainda, vale destacar que neste eixo ocorre um "[...] sensível deslocamento do centro das decisões politicamente relevantes do Legislativo e do Executivo - por eles reputados inertes em direção ao Poder Judiciário, porque a nova magistratura estaria disposta a resgatar as promessas de emancipação inseridas na constituição [...].”28

26 Idem. P. 217

27 MENDES, Gilmar Ferreira; COELHO, Inocêncio Mártines; BRANCO, Paulo Gustavo Gonet (Orgs.). Curso de Direito Constitucional. $3^{\mathrm{a}}$ ed, ver. atual. São Paulo: Editora Saraiva. 2008. P. 58-59

28 KANTOROWICZ, Hermann, A luta pela ciência do direito, in La ciencia del derecho, Buenos Aires: Losada, 1949. P. 323-371.; Apud MENDES, Gilmar Ferreira; COELHO, Inocêncio Mártines; BRANCO, Paulo Gustavo Gonet (Orgs.). Curso de Direito Constitucional. $3^{a}$ ed, ver. atual. São Paulo: Editora Saraiva. 2008. P. 91. 
Nos Estados Unidos da América, por mediação do Direito Costumeiro (common law), que é calcado por precedentes/jurisprudências, apresentam-se assim estes como fontes do Direito Judicial, por via da revisão Judicial, onde se abandona o rígido e inerte arcabouço das normas legais.

Neste eixo, as questões de moralidade política são muito debatidas e são tratadas como questões de princípios assegurados estes pelas Constituições, onde vem o Judiciário a aplicar decisões judiciais com forte cunho político, buscando assim a melhor forma de proteção dos Direitos Fundamentais.

Fator importante, que deu maior estabilidade e legitimidade ao Poder Judiciário, ocorreu com a grande abertura das demandas sociais que vinham a pedir proteção a este órgão, passando este a ter função ativa e garantidora de políticas públicas, se firmando em uma justiça substantiva.

\section{HERMENÊUTICA JURÍDICA CONSTITUCIONAL}

A missão hermenêutica contemporânea, visa dar um caminho efetivamente claro, seguro, e possivel de compatibilizar-se com as necessidades sociais de realização dos direitos constitucionais, por meio de um rigor e objetividade de um labor, onde se tem a liberdade interpretativa, que desta forma, veio a ter pregadores da livre criação do direito, por via do juiz/ tribunal, onde veio a fundar-se em meio das ruínas da dogmática jurídica positivista. Neste sentido Hermann e citado por Gilmar Mendes, tratando, assim:

[...] a atividade hermenêutica, em buscar o rigor e objetividade para o trabalho interpretativo, num movimento que encontrou adeptos no âmbito das ciências do espírito, em geral, e nos domínios da hermenêutica jurídica, em particular, onde aquela preocupação se mostrou ainda mais premente porque, afora os que defendiam a liberdade de interpretação, logo surgiram, também, os pregadores da livre criação do direito, um projeto 
revolucionário que os seus arquitetos imaginavam executar sobre ruínas da dogmática jurídica.

Portanto, e necessário também demonstrar a teoria o Juiz ideal, ou seja, o Juiz Hercules criado por Dwokin, que se diz que o ora juiz tem grande habilidade intelectiva para com suas tarefas, este Juiz é guiado pelos anseios dilapidados e difundidos nas Cartas Políticas, este passará a procurar a melhor interpretação, acobertada esta pela hermenêutica, para assim adequá-la aplicação de suas decisões.

O Juiz Hercules nasceu da insatisfação da sociedade com os demais poderes, passando a assim, a dar legitimidade ao Poder Judiciário, que haja vista, também ganhou este legitimidade pela jurisdição constitucional, estabelecida pelo Poder Constituinte Originário nas Constituições Modernas.

Essa teoria dá liberdade ao Juiz no que tange criatividade/ construtiva do direito por meio da interpretação e da hermenêutica constitucional.

A hermenêutica jurídica constitucional é o caminho efetivamente claro, seguro e possível, para com a busca da realização dos direitos constitucionais, onde por esta têm-se pregadores da livre criação do direito (Savigny) por parte um juiz/tribunal, que se foca na interpretação construtivo-criadora, pois esta surgiu em meio às ruínas da dogmática jurídica positivista.

Ela vem pra ultrapassar a compreensão humana, por meio de direções filosóficas, pra que se torne algo em que a inteligência possa compreender. Compreensão esta, que se dá a partir da pré-compreensão do intérprete, sendo que, se torne algo em que a interpretação é a forma explicita da compreensão. Tem-se aqui por finalidade procurar a melhor luz, do que se requer solução.

Importante falar-se-á que existe uma diferença visível entre interpretação e hermenêutica constitucional, mas também, verse-á que uma depende da outra para que se realize. Ou seja, a hermenêutica detém os meios adequados para a realização da interpretação, neste momento esta ganha à razão de existir/ser, 
quando consegue dar cabo as relações intersubjetivas entre a conjuntura social e as normas jurídicas para com uma aplicação justa, razoável e possível, sendo que, neste ajustamento o Juiz desempenhará o papel de agente redutor de inevitável distância entre a generalidade de preceitos jurídicos e a singularidade dos casos a serem decididos.

Desta forma trouxe severas transformações no que tange a literalidade, frisando-se a da Constituição, que adota modernamente meios axiológicos e principiológicos amplos e flexíveis.

Pelo abalizado, percebe-se que, a interpretação calcada em uma hermenêutica constitucional é construtiva, assim cria-se direito por meio dos juízes, legislando estes negativamente, invadindo assim a competência legislativa quem detém o Poder Legiferante.

A criatividade judicial incide com a aplicação do direito, que vem compor uma qualidade essencial, que o intérprete deve dilatar racionalmente, onde "[...] tanto do ponto de vista objetivo quanto do subjetivo -, ele criará norma concreta, a norma do caso ou a norma da decisão, para efetivamente poder a dar cada um o que é seu e, assim, realizar a justiça em sentido material” 29

A hermenêutica como se vê repousa sobre o reconhecimento da aplicação como momento integrante de toda compreensão, uma vez que, compreender é sempre aplicar, neste sentido precípuo Gadamer, que:

A estreita pertença que unia na sua origem hermenêutica filológica com a jurídica repousa sobre o reconhecimento da aplicação como momento integrante de toda compreensão. Tanto para a hermenêutica jurídica como para a teologia, é constitutiva a tensão que existe entre o texto proposto - da lei ou da revelação - por um lado, e o sentido que alcança sua aplicação ao instante concreto da inter-

29 EHRLICH, Eugen. Fundamentos da sociologia do Direito, Brasilia: Ed. Da Unb, 1986, P. 137; Karl Larenz, Metodologia. ed. De 1989, P. 166-167; apud MENDES, Gilmar Ferreira; COELHO, Inocêncio Mártines; BRANCO, Paulo Gustavo Gonet (Orgs.). Curso de Direito Constitucional. $3^{\text {a }}$ ed, ver. atual. São Paulo: Editora Saraiva. 2008. P. 67 
pretação, no juízo ou na prédica, por outro. Uma lei não quer ser entendida historicamente. A interpretação deve concretizá-la em sua validez jurídica. [...] Aqui, compreender é sempre também aplicar. ${ }^{30}$

Importante que se finalize, a compreensão que integra-se na aplicação, que "[...] passa, necessariamente, pela concepção de uma hermenêutica jurídica que, ultrapassado as concepções metafísico-ontológicas, assuma seu papel de (inter)mediação e, portanto, de produção/construção/adjudicação do sentido.” ${ }_{31}$

Com isso que o processo hermenêutico é sempre produtivo, construtivo e adjudicativo de sentido que a criatividade do julgador ultrapassa a lei, devem assim sempre seguir o que se precípua a Lei Suprema.

A Hermenêutica Constitucional serve de processo de compreensão que ocorre no interior da Hermenêutica, voltados, assim para com a compreensão da acepção das normas constitucionais, onde, se tem um interprete na figura do juiz/tribunal, para dar a soluça entre a norma e o caso concreto.

Vê-se que a grande diferença se dá entre a hermenêutica jurídica e a hermenêutica constitucional redunda em uma questão axiológica de princípios Constitucionais, dilapidados nesta. Há de se elevar, neste momento a questão imbrincada quanto Estado e Constituição, sendo que as decisões tomadas em um âmbito repercutem no outro, por essa aproximação de Estado e teoria da Constituição, ou melhor, entre a hermenêutica constitucional e as concepções corretas de Estado e Constituição, que se consegue identificar a ideologia da fórmula política utilizada pela estrutura jurídico-institucional da sociedade organizada.

Neste sentido corrobora Verdú, citado por Marcio Augusto de Vasconselos, que:

30 GADAMER, Hans-George. Verdade e Método: Traços Fundamentais de uma Hermenêutica Filosófica. $3^{\text {a }}$ ed. Tradução: Flávio Paulo Meuer. Petrópolis: Vozes, 1997. P. 451.

31 STRECK. Lênio Luiz. Hermenêutica e(m) crise: uma explosão hermeneutica da construção do Direito. Porto Alegre: Livraria do Advogado, 1999. P. 226. 
Uma discussão em torno da hermenêutica constitucional, uma das mais importantes expressões da hermenêutica jurídica contemporânea, sempre é, também, um questionamento acerca das relações entre Estado e Constituição, pois as decisões prévias tomadas num âmbito repercutem necessariamente no outro. É justamente a partir desta proximidade entre hermenêutica constitucional, teoria do Estado e teoria da Constituição - ou melhor, entre a hermenêutica constitucional e as concepçães concretas de Estado e de Constituição - que se pode identificar a ideologia, ou fórmula política (Pablo Verdú), em que se alicerça a estrutura jurídico-institucional da comunidade politicamente organizada. ${ }^{32}$

Menciona-se pelo exposto, que, o processo hermenêutico é sempre produtivo, construtivo e adjudicador de sentido, assim, a criatividade do julgador vai além do mero texto de lei, sendo que, este adaptará o texto de acordo com a Lei Fundamental, ou seja, com a Constituição, que são regidas por normas, divididas em regras e princípios axiologicamente abertos, pois feito isto, estarão cumprindo seu papel de guardiões da constitucionalidade das leis

Aqui vale salientar quanto à carga substancial da Constituição, pois esta ganha por si status de hermenêutica que conformará a interpretação jurídica, já quanto sua carga material, esta reflete na ordem jurídica social.

Tanto a hermenêutica quanto a interpretação constitucional, calcam-se em dois princípios, sendo eles: o princípio da presunção de constitucionalidade, que reside em uma esfera abstrata; e o princípio da unicidade constitucional; ambos representando papel fundamental, dando abertura e plasticidade das normas jurídicas.

32 VERDÚ, Pablo Lucas. Curso de Derecho político. $3^{\text {a }}$ ed. Madrid: Tecnos, 1986, v. II, Cap. 6.; apud DINIZ, Márcio Augusto de Vasconselos. Constituição e hermenêutica constitucional. $2^{\mathrm{a}}$ ed. Belo Horizonte: Mandamentos, 2002. P. 233. 


\subsection{Interpretação Jurídica Constitucional}

Quanto à Interpretação Constitucional, este vem somente dar complementaridade, pois, se liga íntimamente com a Hermenêutica Constitucional. Vale mencionar o que ensina Celso Ribeiro Bastos, a cerca do objeto da interpretação, dizendo que, o objeto é: "[...] o texto constitucional com suas regras e princípios, enquanto portador de um significado ou sentido, cuja compreensão plena é o objetivo final da interpretação." ${ }_{33}$

Salutar apresentar, que esta tem como objetivo a interpretação do texto constitucional, onde por si só esta, cria direito por via das Cortes Constitucionais, assim buscando a regeneração dos modelos judiciais, para que haja o ajustamento e atualização do ordenamento jurídico por intermédio do intérprete.

A interpretação conforme a Constituição é um instituto hermenêutico constitucional, que se tem alargado diante do Estado Democrático de Direito, como já visto em outros tópicos. Foi neste modelo de Estado que a Jurisdição Constitucional assume lugar absolutamente diferenciado daquele que se tinha diante do Estado de Direito Clássico, ou Liberal de Direito ou até mesmo do Estado Social de Direito, onde diante do exposto, finaliza-se com o pensamento de Streck, que:

[...] parece razoável afirmar que sua configuração longe está do paradigma que consubstanciou a hermenêutica clássica, de caráter reprodutivo. Trata-se de um instituto construído pela tradição jurídica visando à otimização dos textos jurídicos, mediante agregação de sentidos, portanto, produção de sentido. ${ }^{34}$

Por derradeiro, vê-se que, a hermenêutica se fundou, tornando um topos paradigmático, sendo que foi construído ao longo dos anos, desde que o Estado Moderno se fundou e que não inquieta-se até os dias da contemporaneidade, refle-

33 BASTOS, Celso Ribeiro. Hermenêutica e Interpretação Constitucional. $3^{a}$ ed. São Paulo: Celso Bastos, 2002. P. 143.

34 STRECK, Lênio Luiz. Jurisdição Constitucional e Hermenêutica - Uma nova crítica do direito. Porto Alegre: Livraria do Advogado, 2002. P. 449. 
tindo essa inquietação, na questão quanto ao interpretar para que melhor dizer buscar o sentido do objeto, ou seja do Texto Constitucional.

Portanto a interpretação constitucional é considerada como um procedimento operativo de controle de constitucionalidade das leis e de atos normativos, por via dessa operatividade deve-se preservar a Supremacia Constitucional, sendo assim, os Juízes e Tribunais tornam-se ativistas Judiciais à eles cabendo a interpretação final da Carta Política.

\subsection{Interpretação Criadora/construtiva de Direito}

A interpretação criadora construtiva dá-se pelo liame entre a hermenêutica e a interpretação constitucional, assim defenderse-á essa tese pelo Ativismo Judicial Substantivo, por intermédio desta interpretação construtiva criadora, nasce direito através dos juízes e tribunais, como uma verdadeira transparência, de onde se detém resultados práticos com maior efetividade

Nasce essa interpretação forçosamente para que se venha ser repensado quanto à dogmática jurídica.

A criatividade dos Juízes, como se verá diante de todo o trabalho, que cresce a passos largos, têm em vista os casos apresentados em capítulo anterior, de decisões judiciais que foram amplamente criativo-construtivas, onde tem como base Constituição, que por meio da jurisdição constitucional, tais decisões foram exaradas pelas Cortes ou Juízes, tornam-se decisões políticas. Também se alude que as decisões jurídicas passam a tornarem-se fontes seguras do ordenamento jurídico. Também se alude que as decisões jurídicas passam a tornarem-se fontes seguras do ordenamento jurídico.

Este processo de criação construtiva criador de direito, deve ser levada em conta, juntamente com a realidade política. Corrobora Fried Reis:

[...] é a interpretação judicial que resultarão os efeitos práticos, de caráter definitivo, para todos os 
jurisdicionados (no caso de interpretação de uma norma in concreto por um juiz singular) ou mesmo para toda a sociedade ( no caso de interpretação de uma norma in abstrato realizada pelos tribunais, especificamente pela Suprema Corte). ${ }^{35}$

Quanto ao que se discute sobre a segurança jurídica e, por essa via interpretativa que ela passa a realizar de modo mais adequado, por via da hermenêutica constitucional e pela riqueza semântica contida no princípio da justiça, faz com que o julgador tome decisão mais segura e cheia de certeza.

\subsection{Polítização do Direito pela via Judicial}

A politização do direito por via judicial é chamada de Ativismo Judicial Substancialista, que ganha espaço constitucional e é realizado pelos Tribunais e Juízes, que detém em suas mãos a Jurisdição Constitucional, que por meio de suas decisões.

Decisões Políticas, sendo que elas passam a interferir diante dos demais poderes estatais, sendo assim, suas decisões passam a ter cunho político, para com a realização de políticas públicas não realizadas e não efetivadas pelos demais órgãos estatais.

Estas decisões têm a mesma "carga" que as decisões judiciais, resultante de uma proximidade da jurisdição constitucional com a função de gerência para com a configuração política, onde passa a se decidir questões mais numerosas com toque político e de alcance político do que as demais jurisdições.

Assim aduz o egrégio autor:

Essas particularidades resultam das relações próximas da jurisdição constitucional com as funções da direção e configuração política. A jurisdição constitucional tem de decidir questões mais numerosas com toque político e de alcance politico do que outras jurisdições. Suas próprias decisões podem desdobrar efeitos políticos de alcance

35 FRIEDE, Reis. Ciência do Direito, Norma, Interpretação e Hermenêutica Jurídica. 3a. ed. Rio de Janeiro: Forense Unoiversitária, 2000. P. 141 
considerável. Elas podem avizinhar-se de uma decisão política, tanto mais que elas regularmente podem ser obtidas não sobre a base de normalizações detalhadas, senão somente com base nos critérios amplos e indeterminados da Constituição. A realização dessas decisões, finalmente, está sujeita a condições completamente diferentes do que aquelas de outras decisões judiciais. ${ }^{36}$

Portanto, as decisões jurisdicionais constitucionais têm um efeito altamente criativo/construtivo, que se incide através da hermenêutica e da interpretação constitucional, desta forma criando direito por estas vias, pois as suas decisões tornam-se, assim políticas, ainda mais quando o Tribunal, pela jurisdição constitucional, passa a regular os demais órgãos que compõe o Estado. Resume-se que, como intuitivo, do Ativismo Judicial "[...] envolve uma transferência de poder para juízes e tribunais, com alterações significativas na linguagem, na argumentação e no modo de participação da sociedade." ${ }^{37}$

Conclui-se que as Decisões Políticas influenciam para com a Criação de Direito pelas Cortes Constitucionais, pois o texto constitucional é necessariamente uma interpretação deste, onde por meio da hermenêutica constitucional este texto tem alto nível e carga política.

\section{CONCLUSÃO}

Diante disto, conclui-se que, com o advento do nascimento e evolução do Estado de Direito, percebeu-se, que o modelo de Estado Liberal, era regido pelo governo das leis, sendo o juiz mero aplicador de leis, onde no modelo de Estado Social, houve o fortalecimento do Poder Judiciário por meio da Jurisdição Constitucional, criada por Kelsen na Áustria, e

\footnotetext{
36 HESSE, Konrad. Elementos de Direito Constitucional da República Federal da Alemanha. Tradução (da 20ª Edição alemã) Luís Afonso Heck. Porto Alegre: Fabris Editor, 1998. P. 420-421.

37 BARROSO, Luís Roberto. Judicialização, Ativismo Judicial e Legitimidade Democrática. Disponível em: <http://www.oab.org.br/oabeditora/users/revista/1235066670174218181901.pdf>. Acessado em: 12, de maio de 2009.
} 
utilizada nos Estados Unidos, no caso paradigmático da decisão prolatada por Marbory.

A partir destes elementos o juiz têm novas funções, mas estas somente são reconhecidas diante do Estado Democrático de Direito, frente a uma crise do dogmatismo positivista, vendose que este não consegue mais acompanhar a velocidade das mudanças das sociedades modernas. Assim o juiz, usar-se-ia de suas funções, sendo que, por este motivo, criaria direito por meio de suas decisões.

Frente às considerações acima exaradas, vê-se que diante de um quadro Constitucional e Judiciário criado pelo modelo de Estado Democrático de Direito, efetivou-se este no pós-guerra, onde o Judiciário assim, ganha legitimidade mediante o estabelecido pelo Poder Originário Constitucional, sendo que com o aceite das sociedades, para intervir como sendo o "guardião das promessas" dilapidadas frente aos Textos Constitucionais, esculpiriam-se os Direitos Fundamentais, a serem assegurados, assim podendo este "órgão" intervir com suas decisões diante das demais esferas políticas do Estado, por via da revisão judicial, onde mais adequadamente deve ser chamada de controle de constitucionalidade das leis e atos normativos. Portanto, é notório que nasce assim o neoconstitucionalismo, onde o Judiciário deixa de ser um ente pacífico e passa a buscar a realização de uma politização do Direito afetando desta forma a conjuntura política das democracias contemporâneas.

Esse novo quadro judiciário, é tido como Ativismo Judicial, onde deste nascem duas correntes, sendo elas, a procedimentalisa e a substancialista. Na corrente procedimentalista há de se concluir que não prosperará diante do Estado Democrático de Direito, pois sua tese busca a racionalização do direito por via de leis, voltando-se assim ao Estado Liberal de Direito, reputa-se esta tese por voltar a um "governo das leis", fazendo com que o juiz e os Tribunais, apliquem somente o que se está codificado. Quanto ao Ativismo Judicial Substancialista, este demonstra-se próspero diante do Estado Democrático de Direito, onde o juiz 
por sua interpretação construtiva/criadora de direito, decide de forma mais adequada, utilizando-se do princípio da justiça, onde por vezes este toma decisões de cunho político, interferindo assim profundamente tanto no Poder Legiferante quanto no Poder Executivo. Ocorre desta forma, a Politização do Direito por via judicial, onde se cria um novo paradigma o qual o juiz transformou-se em partícipe da sociedade e defensor da democracia por meio prestação jurisdicional que lhes é dada por via da existência de uma Jurisdição Constitucional, que passa a provocar transformações políticas, sociais e econômicas. Concluiu-se portanto, que os juízes legislem negativamente, segundo os ditames abordados pela teoria substancialista, através da Hermenêutica e da Interpretação Jurídica Constitucional. Estas correntes doutrinarias dão alto grau de substancialismo diante de suas interpretações aos casos que lhes são dados a resolver. O Ativismo Judicial Substancialista, passa a usar-se de interpretação, e esta utiliza-se da Hermenêutica Jurídica Constitucional, onde passou a transformar o juiz no mais importante "guardião das promessas" da Constituição, fazendo com que esta efetive-se e realize-se por meio dos direitos fundamentais, sendo assim, o defensor contra as violações destas garantias consubstanciadas pelos próprios poderes, passando assim as suas decisões terem cunho político, pois como visto atingem as demais Esferas Públicas. Reconheceu-se que realmente o juiz cria direito de modo transparente, onde o Ativismo Judicial Substancialista tem sido extraordinariamente beneficente para que se venha a romper o formalismo do Direito, abrindo novos espaços diante do ordenamento jurídico.

Abstract: Investigates the study the Evolution of the State of Law, demonstrating the growthtangential of the Judiciary, strengthened by the new Constitutional models, which provide support for a more interference in its Courts. Therefore, the Judiciary became the "create right" by means of its activity, legislating negatively, because this is 
a Political Power that uses the legal interpretation constitutional constructive, called for Judicial Activism.

Keywords: State. Constitution. Constitutional Jurisdiction. Judicial Activism. Hermeneutics.

\section{REFERÊNCIAS}

AGUIAR, Thais Florencio de. A judicialização da política ou o rearranjo da democracia liberal. Ponto-e-Vírgula, 2: 142-159, 2007. P. 150. Disponível em: 〈http://www.pucsp.br/ponto-e-virgula/n2/pdf/11-thais.pdf>. Acessado em: 29, de janeiro de 2008.

BAEZ, Narciso Leandro Xavier; BARRETO, Vicente (Orgs.) Direitos Humanos em evolução. 1a ed. Joaçaba: Ed. UNOESC

BASTOS, Celso Ribeiro. Hermenêutica e Interpretação Constitucional. $3^{a}$ ed. São Paulo: Celso Bastos, 2002.

BARROSO, Luís Roberto. Judicialização, Ativismo Judicial e Legitimidade Democrática. Disponível em: 〈http://www.oab.org.br/oabeditora/users/ revista/1235066670174218181901.pdf>. Acessado em: 12, de maio de 2009.

BOBBIO, Norberto. Liberdade e Democracia. 4o. ed. São Paulo: Editora Brasiliense, 2000.

CANOTILHO, José Joaquim Gomes. Direito Constitucional - e teoria da constituição. 6ª ed. Coimbra: Almedina, 1993.

CAPPELLETTI, Mauro. Juízes Legisladores? Tradução: Carlos Alberto Álvaro de Oliveira. Porto Alegre: Fabris, 1993.

COSTA, Pietro; ZOLO, Danilo (Orgs.).O Estado de Direito. História, teoria, crítica. 1a ed. São Paulo: Martins Fontes. São Paulo 2006.

DINIZ, Márcio Augusto de Vasconselos. Constituição e hermenêutica constitucional. 2a ed. Belo Horizonte: Mandamentos, 2002.

DWORKIN, Ronald. O Império do Direito. $1^{\text {a }}$ ed. São Paulo: Martins Fontes, 1999.

ESPINDOLA, Ruy Samuel. Jurisdição Constitucional Estadual. Revista Direito Público. Pág. 383 - 384. Disponível em :<hattp://201.38.128.50/ 
ojs/index.php/direitopublico/article/view/86>. Acessado em: 13 de mao de 2008.

FRIEDE, Reis. Ciência do Direito, Norma, Interpretação e Hermenêutica Jurídica. 3a. ed. Rio de Janeiro: Forense Unoiversitária, 2000.

GADAMER, Hans-George. Verdade e Método: Traços Fundamentais de uma Hermenêutica Filosófica. 3a ed. Tradução: Flávio Paulo Meuer. Petrópolis: Vozes, 1997.

GARAPON, Antoine. O juiz e a democracia. O guardiao das promessas. Tradução: Maria Luiza de Carvalho. 2a ed. Rio de Janeiro: Revan, 2001.

GOMES, Sergio Alves. Hermenêutica Jurídica e Constituição no Estado de Direito Democrático. Rio de Janeiro: Forense, 2001.

HESSE, Konrad. Elementos de Direito Constitucional da República Federal da Alemanha. Tradução (da 20a Edição alemã) Luís Afonso Heck. Porto Alegre: Fabris, 1998.

JAYME, Fernando Gonzaga. Tribunal Constitucional: exigência democrática. Belo Horizonte: Editora Del Rey, 1999.

KELSEN, Hans. Teoria Geral do Direito e do Estado. $3^{a}$ ed. São Paulo: Martins Fontes, 2000.

LEAL, Roger Stiefelmann. A Judicialização da Politica. Disponível em <http://www6.ufrgs.br/ppgd/doutrina/leal1.htm>. Acessado em: 04, de março de 2009.

MENDES, Gilmar Ferreira; COELHO, Inocêncio Mártines; BRANCO, Paulo Gustavo Gonet (Orgs.). Curso de Direito Constitucional. 3a ed, ver. atual. São Paulo: Editora Saraiva. 2008.

PUIG, Santiago Mir. El Derecho Penal en El Estado Social y Democrático de derecho. 1'a ed. Barcelona: Editora Ariel, 1994.

STRECK, Lênio Luiz; MORAIS, José Bolzan de. Ciência Política \& Teoria do Estado. 5a ed. Porto Alegre: Editora Livraria do Advogado, 2006.

STRECK, Lênio Luiz. Jurisdição Constitucional e Hermenêutica - Uma nova crítica do direito. Porto Alegre: Livraria do Advogado, 2002.

STRECK. Lênio Luiz. Hermenêutica e(m) crise. Porto Alegre: Livraria do Advogado, 1999. 